\title{
Use of modern computer technologies and 3D modelling in the study of historical montanistics
}

\author{
Henrieta Pavolová ${ }^{1}$ Zuzana Šimková ${ }^{*}$, and Miloš Petráš ${ }^{1}$ \\ ${ }^{1}$ Technical University of Košice, Faculty of Mining, Ecology, Process Control and Geotechnologies, \\ Institute of Earth Resources, Park Komenského 19, 04200 Košice, Slovakia
}

\begin{abstract}
This paper points out the integration of using of modern computer technologies and 3D modeling of montaneous objects, which form an integral part of montaneous tourism. It describes in detail the chronological development of the term " montaneous ", which currently refers to all areas with interaction ties to primary, secondary and tertiary spheres of mining. At the same time, it points to an attractive form of making available objects, which no longer exists, resp. inaccessible historical montaneous objects using 3D visualization for the general public, which requires not only wider teams of high-quality programmers or graphic designers, but also experts who create historically relevant descriptive texts, diagrams or models, according which is possible their computer processing. Finally, it presents concrete 3D visualizations of historical montaneous objects in the territory of Eastern Slovakia.
\end{abstract}

\section{Introduction}

At presnet science, the concept of Montaneous is understood very inconsistently, diversity and often incorrectly, not only in connection with mining activities, therefore its methodological clarification is necessary at the beginning of the study. In Central European, or rather more precisely in the Czech-Slovak geographic space, the correct explanation of the term montaneous (Montanism) in the intentions of history, historical geography, environmental history or mining history must be understood in a broader conceptual context based on older scientific works. The concept of monaneous must be understood much broader than the mining itself (including mining of raw materials) and include also metallurgy, accompanying crafts and so on. Here it is necessary to point out at the beginning that we do not work with the term montaneous in the meaning of mountain, which is used as a terminus technicus eg. in geomorphology, landscape ecology, botany, zoology and the like.

Nowadays commonly used terms montaneous, montanistics, montanist are derived from the Latin word Mons in the meaning of mountain (m. No. Montis) [1], which we can translate in the primary sense as a mountain, mountain or mountain, respectively in the meaning of stone, rock, or boulder [2]. This term has been used to refer to historical mining (ie including metallurgy) since the 19th century [3]. Gradually, it began to settle down in

\footnotetext{
* Corresponding author: zuzana.simkova@tuke.sk
} 
Austrian German [4], eg. Montanuniversität Leoben in Leoben, Austria, or the older term K. by K. Montanärar (Imperial Royal Montana Administration) and similarly.

The term montanistics comes from the German word Montanistik (Montanwissenschaften, Montanwesen). It is an older term referring to the montan industry, ie. j. mining and metallurgy, e.g. das Bergbau- und Hütenwessen betrefend [1] montanistic t. c. mining, upper [5], montanisticum, mining and metallurgy [6] and similarly. It also denotes montane sciences, i. j. mining and metallurgical sciences (science of mining and metallurgy, Bergbaukunde), e.g. Montanistics, mining science [7].

Nowadays, the term "montanistics" cannot be simplified only to the synonym for mining, because the term "montaneous" is broader and much more complex than current (modern) mining and also refers to the metallurgical science segment and other related branches and employment. It is very closely related to economics, water management (drainage, use of hydropower, water transport), forestry (as a fuel base for smeltery or material for mines), transport, education, traditions and so on. It also concerns ironmongery, non-ferrous metallurgy, processing, oil and gas extraction, geodesy, power engineering, petrochemistry, geology, rock mechanics, petrography, engineering, prospection, geological and deposit prospecting, drilling and similarly. Nowadays, the field of mining sciences is more often referred to as mining engineering according to the English model. Nowadays (since the 20th century) montaneous is also one of the mining issues.

At present, scientific research uses computer technologies to a great extension. History in the Slovak scientific environment lags significantly behind. The only exception is a narrow team grouped around prof. P. Chrastina and Dr. L. Župčán at Trnava University. Leaders in historical research using modern technology are archaeologists at the Archaeological Institute of the Slovak Academy of Sciences in Nitra. These scientists hardly ever (except P. Chrastin) devote themselves to computer reconstructions in Montanistic.

\section{Development of the research of historical montaneous using modern computer methods at the Technical University of Košice}

From the above information we could conclude that the research of historical montanistics represents a multilateral issue of interdisciplinary nature, which requires a team of researchers assembled from montaneous experts. In recent years, researchers at the Technical University of Košice from the Institute of Earth Resources have been intensively dealing with the research of historical montanistics phenomena, who as part of interdisciplinary research, are gradually examining historical phenomena and processes in montanistics with the application of 3D models. They focus on areas with absent, respectively insufficient archival documents. It is the historical areas, where only minimal written and cartographic sources have been preserved, that represent the basal platform of research, where computer modeling is the basic source of (new) historical information. The first research team began to form at the end of the first decade of the new millennium under the leadership of a major montanistics and professor of mining history prof. Pavol Rybár.

It was this team that began to integrate modern computer technologies and 3D modeling, which they used in the field geotourism (Information technologies in geotourism) [8], in the reconstruction of historical montaneous territories and historical mining objects, to support the development of tourism (Reconstruction of historical mining teritory by information technology [9], Aplication of GIS to the model of the old mining objects and their exploitation in tourism [10]). They also used GIS to categorize and visualize historical data (Information technologies in montaneous tourism [11]), which were later applied in Central Europe (Mediaval salt routes leading through the territory of 
Slovakia [12], Medieval salt routes in Slovakia [13], Salt routes in Slovakia in the middle ages [14]).

Since 2015, a team of experts in montanistics and mining history has been involved in the research of environmental history of the montaneous country in several partial research studies Computer modelling as a basic research and visualisation tool to research defunct historical mining technologies, using the example of cementation water mining in Smolník (Slovakia) [15], Relics of manual rock disintegration in historical underground spaces and their presentation in mining tourism [16], Historical blast furnace in Peklo valley of Lubietová (Slovakia) and its reconstruction using 3D modelling [17]).

Currently, the research team of experts focus on using a complex of research methods to solve geotechnical problems such as reconstruction of historical water reservoirs, activation of old landslides, remediation of landslide slopes in a mining country with still active mining activity. He used methods of geodetic monitoring, 3D modeling of montaneous objects and geological environment, which he presented in his work Multidisciplinary research of landslide at UNESCO site of Lower Hodruša mining water reservoir [18].

He also focused on mapping of montaneous objects, modeling, virtual reconstructions and $3 \mathrm{D}$ visualization of extinct mining workings and montaneous facilities, utilization of results in support of montaneous tourism in former mining localities in the works Geographical-montanistics research in mining locality Smolník and virtual reconstruction of historical mining workings (Fig. 1.) [19], 3D visualization of old mining workings in Central Slovakia and their presentation on the internet [20], Field research and digital modeling of relicts of old mining shafts [21]. He uses non-standard methods and stereophotogrammetry for virtual reconstruction and derivation of positional-dimensional properties of objects of original montaneous landscape such as in work Using historic postcards and photographs for the research of historic landscape in geography and the possibilities of their digital processing [22].

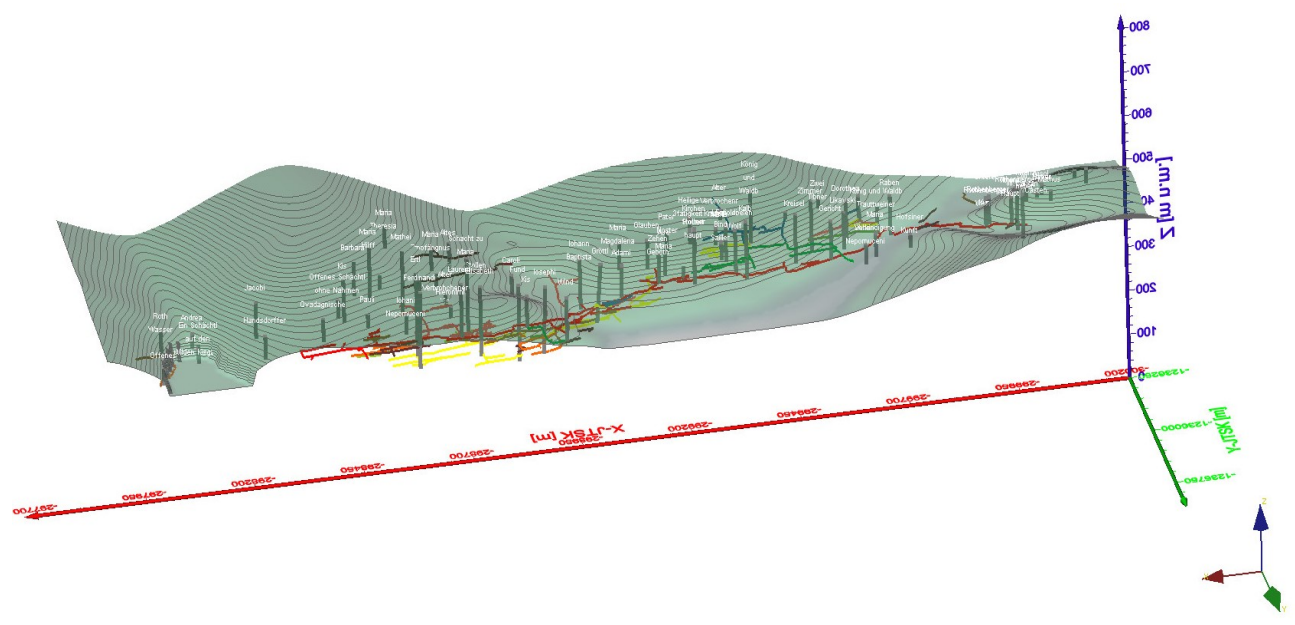

Fig. 1. 3D model of mines in Smolník under the Rotenberg Hill (the second half of the $19^{\text {th }}$ century)

Source: [19] 
In solving and researching various (usually specific) pending historical problems in the field of montanistics, based on archival and field research, in the last year, in addition to 3D modeling, they also used methods of lidar scanning of montaneous landscapes presented in the works: 3D model of selected cultural monument based on contemporary historical and graphical sources [23], Display of the landscape and settlement at the confluence of Vel'ká Michalová and Rohozná in old maps [24], Reconstruction of the lost genius loci of the medieval landscape at the confluence of Kysuce and Radola, where the reconstruction of the defunct Gothic church from the 14th century was realized in 3D space, which was allocated in real country (Fig. 2.) [25].

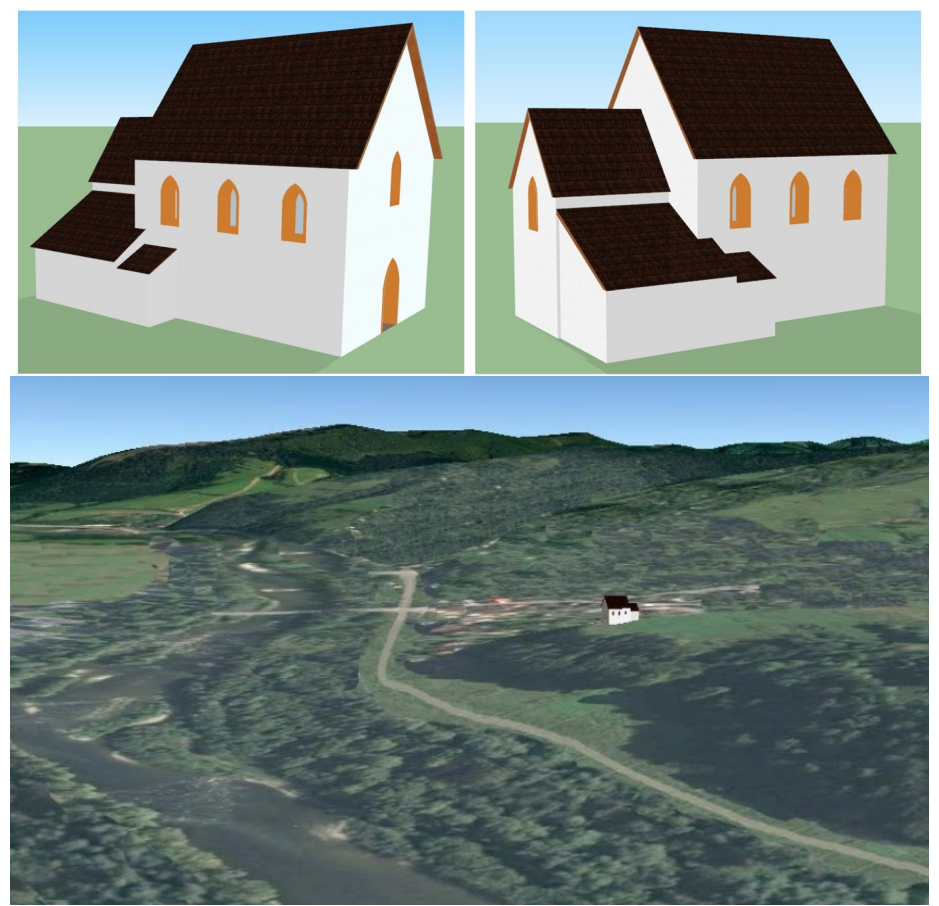

Fig. 2. The reconstruction of the Gothic church in Radola

Source: [25]

\section{Research of historical montaneous phenomena on the example of mining towns in Eastern Slovakia}

The montaneous research was realized by a team from TU in Košice in many locations in eastern Slovakia. As an example we can mention Spišská Nová Ves, or its mining settlement Novoveská Huta, Gelnica and Smolník. We will present a different montanistics phenomenon in each area by using 3D models. In Novoveská Huta we will focus on the inaccessible mining underground of historical mines of copper-ore, from Gelnica we will present the reconstruction of Gelnice Castle as a historical point within the forming medieval mining town of Gelnica. In Smolník we will present through the 3D models of inaccessible montaneous underground, which were excavated in order to obtain copper by cementation. 
The first reports of copper-ore mines in the Strážny Hill (898MASL) are from the 16th century. The most important area was Leithaus, later associated with the mining activities by Johanns. It was at the area of the Johani shaft where at the end of the 19th century was established the Novoveské Spa, whose relicts overlap the original montaneous heritage in the country. Based on the 3D model the underground inaccessible spaces of the copper-ore mines (some extinct) have been processed, as they were recorded by historical sources at the end of the 19th century (Fig. 3.).

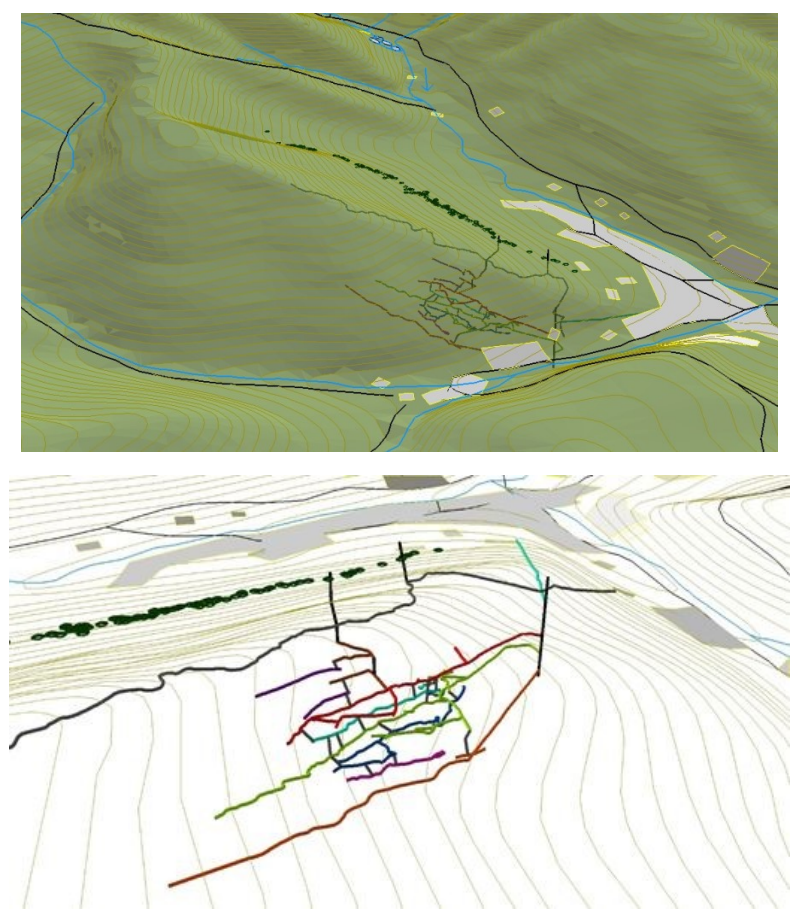

Fig. 3. 3D model of the historical montaneous copper-ore underground

Source: [15]

The research in Gelnica was focused not only on the visualization of the mining underground and the creation of 3D models of old mining spaces, but also on the visualization of ore veins in the Gelnice deposit area. For the purposes of the study, however, we mention as an example reconstruction 3D model of defunct Gelnica Castle, which was directly related to the occurrence of mining in the region. Gelnice Castle was built in the 13th century on the outskirts of the city in a location called Zámčisko in order to protect the city and its mines. Since the first half of the 16th century the castle was in ruins and served as a quarry for the construction of the city Gelnica. At present, only a few architectural elements have been preserved from the castle. Processed 3D reconstruction brings appearance of the castle before its demise. The gradual process of 3D visualization of Gelnica Castle, gradually wrapping the architectural material on the old drawings shows Fig. 4. and the supposed appearance of Gelnica Castle before its destruction and abandonment in the first half of the 16th century illustrates Fig. 5. 

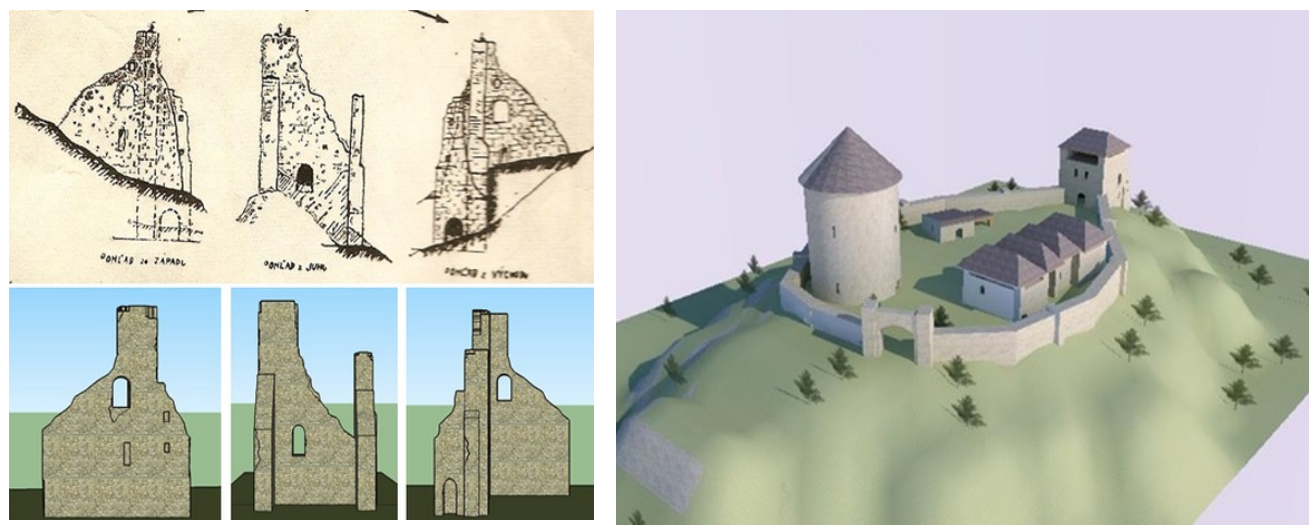

Fig. 4. The 3D visualization of Gelnica Castle

Source: [23]

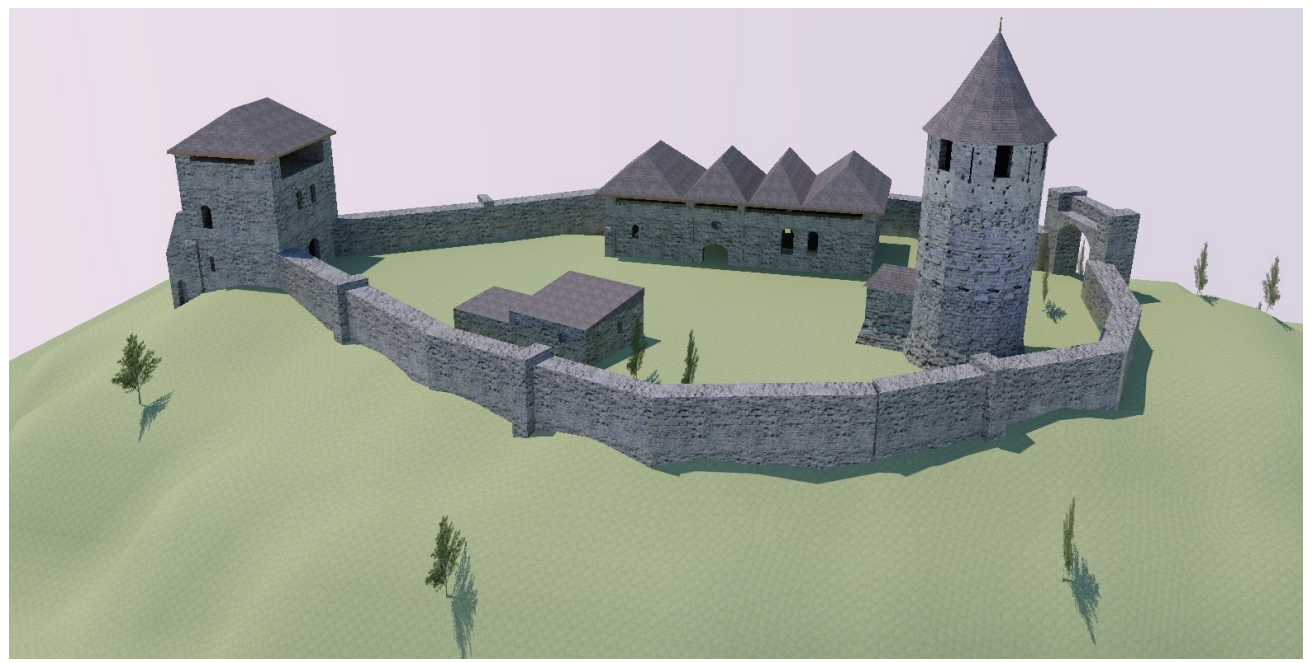

Fig. 5. The supposed appearance of the Gelnica castle

Source: [23]

The research team from Technical University of Košice also dealt with 3D visualization of montaneous issues in Smolník. Here reconstructed a unique water management system used to supply water to the targeted excavated underground, where water was saturated with copper sulphate $\left(\mathrm{CuSO}_{4}\right)$. This water was subsequently extracted from the underground and copper was recovered on the surface by the cementation process in gutters. It is the second oldest economically used cementation process in the world, which was used already in the 14th century. It continued until the 20th century. Since the relics of the water management system have been partially preserved up to now, we present an example in the form of a non-existent specific montaneous underground excavated for the mining of enriched water. It is an underground under the Rotenberg Hill, how it was recorded by historical sources in the first half of the 19th century (Fig. 6.). 


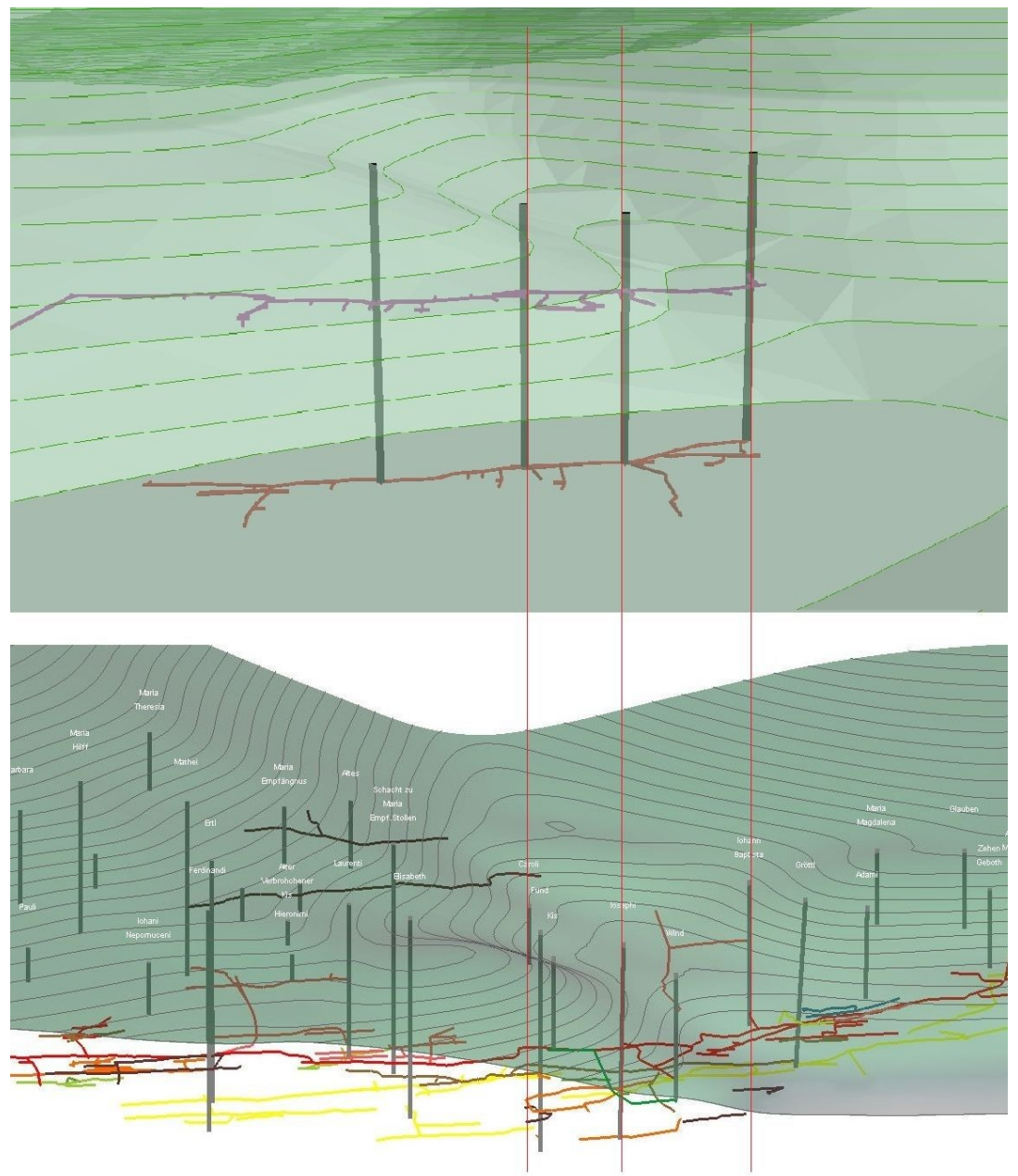

Fig. 6. Mining underground excavated for cementation in Smolník

Source: [19]

\section{Conclusion}

The phenomenon of the last decades to which we have become extremely accustomed is digitization. It has penetrated all spheres of our lives, including cultural and historical heritage. Classical forms of information are transformed into digital, what generally facilitates access to them, or modeling creates new, previously unknown information in history. It allows us to transfer virtually to places where we wouldn't otherwise be able to travel and see objects that otherwise cannot be seen. It is therefore clear that digital technologies have undoubtedly great application in the field of (mining) substantive, but also intangible heritage, not only in the visualization of existing objects, but especially in the creation of models of extinct objects. This process allows objects that no longer exist to be preserved for humanity in the form of a digital heritage.

$3 \mathrm{D}$ models allow you to view montaneous objects from every side or angle, to move not only in the underground, but also to walk through entire mine from the surface to the deepest points. The models allow view the landscape (underground) or its elements (often 
no longer existing) from any point of view. Another advantage is that it is possible to look at the landscape, underground, or different object in different time horizons, of course, if the technical and content processing of the models allows it.

Another advantage of computer modeling of $3 \mathrm{D}$ models is that in addition to the primary, by modeling of visually obtained and directly visible and measurable parameters of the montaneous landscape and its objects, it is possible to derive from the digital model also secondary parameters that are invisible in historical materials. This process - research, however, requires expertise, so 3D models are also used in the scientific field, especially in montanistics, montaneous geomorphology, history, environmental history, etc.

\section{References}

1. H. J. Meyers. Konversations-Lexikon: eine Encyklopädie des allgemeinen Wissens (Bibliographisches Institut, Leipzig, 1890)

2. J. Špaňák. Dictionarium Latino-Slovacum (Aedes Paedagogicae Slovacae, Bratislava, 1987)

3. Kolektív. Propedeutik der Geschichte, oder Historische Vorbereitungs- und Hulfswissenschaften (Wien, 1821)

4. W. K. R. Haidinger. Das Kaiserlich-Königliche montanistische Museum und die Freunde der Naturwissenschaften in Wien in den Jahren 1840-1850 (Braumüller, Wien, 1896)

5. Kolektív. Ottův slovník naučný: illustrovaná encyklopaedie obecných vědomostí (J. Otto, Praha, 1901)

6. K. Kavina. Naučný slovník přirodních věd pro školu a dům. (Elstner, Praha, 1942)

7. V. Teyssler, V. Kotyška. Technický slovník naučný: ilustrovaná encyklopedie věd technických. (Borský a Šulc, Praha, 1932)

8. P. Rybár, L. Hvizdák, M. Molokáč, J. Hvizdáková. Information technologies in geotourism. Geotourism and Montaneous tourism, 50-53 (2010)

9. P. Rybár, L. Hvizdák, M. Molokáč, J. Hvizdáková. Reconstruction of historical mining teritory by information technology. Pokročilé technológie $\mathrm{v}$ oblasti získavania a spracovania surovín .196-198 (2011)

10. L. Hvizdák, M. Molokáč. Aplication of GIS to the model of the old mining objects and their exploitation in tourism. SGEM, 965-972 (2012)

11. P. Rybár, L. Hvizdák, M. Molokáč, J. Hvizdáková. Acta Geoturistica 1, 2 (2010)

12. P. Rybár, J. Engel, M. Molokáč. Mediaval salt routes leading through the territory of Slovakia. IRSE' 09, 7-19 (2009)

13. P. Rybár, J. Engel, M. Molokáč. Medieval salt routes in Slovakia. Mining in the Central Europe through history. 13-22 (2010)

14. M. Molokáč. Salt routes in Slovakia in the middle ages. (VŠB Technická univerzita, Ostrava, 2013)

15. P. Rybár, L. Hvizdák, P, Hronček, M. Jesenský. Acta Montanistica Slovaca. 22, 3 (2017)

16. P. Hronček, P. Rybár. Acta Montanistica Slovaca. 21, 1 (2016)

17. P. Hronček, P. Rybár. Acta Montanistica Slovaca. 21, 4 (2016) 
18. M. Bendárik, R. Putiška, I. Dostál, R, Tornai, K. Šilhán, F.Holzer, K. Weis, I. Ružek. Multidisciplinary research of landslide at UNESCO site of Lower Hodruša mining water reservoir. (Springer Berlin Heidelberg, Berlin, 2018)

19. K. Weis. P. Bednárik, M. Masný. Geografické informácie: časopis Katedry geografie a regionálneho rozvoja FPV UKF v Nitre. 20, 2 (2016)

20. K. Weis, S. Jeleň, P. Bednárik. $3 D$ visualisation of old mining works in Central Slovakia and their presentation on the internet (Slovenské banské múzeum, Banská Štiavnica, 2015)

21. P. Hronček, K. Weis. Terénny výskum a digitálne modelovanie reliktov starých banských štôlní. Geografická revue. 10, 98-131 (2014).

22. K. Weis, P. Hronček. Using historic postcards and photographs for the research of historic landscape in geography and the possibilities of their digital processing. European journal of geography. 8, 77-85 (2017)

23. L. Župčan, P. Hronček, M. Durčo. 3D model of selected cultural monument based on contemporary historical and graphical sources. Geotur 2018. 27 - 27 (2018)

24. P. Hronček. Zobrazenie krajiny a sídla na sútoku Vel'kej Michalovej a Rohoznej v starých mapách. 79-110 (2018)

25. P. Hronček, M. Jesenský, P. Jančura. Acta Regionalia. 2, 1-2, (2017) 